\title{
THE GARDNER A. SAGE THEOLOGICAL LIBRARY
}

\author{
$B Y$ DANIEL JAMES MEETER
}

Rev. Meeter is Pastor of the First Reformed Church of South River, New Jersey

$7 \mathrm{HE}$ holdings and the history of Gardner A. Sage Library reflect the history of the Dutch settlers in America, whose 1 colony between Connecticut and Maryland was taken over
by the British in 1664 , but whose language and culture endured another century and a half, nurtured by their Calvinistic religion. As soon as the first settlers came to Nieuw Amsterdam (New York City) they began to meet informally for worship. In I628 a congregation was officially organized according to the laws of the mother church in the Netherlands, which sent them a minister. From this first organization has grown the Reformed Church in America, often called "the Dutch Reformed Church," the oldest continuing Protestant church in America. In 1784 this church established the nation's first theological seminary, which is celebrating its two-hundredth anniversary this year in New Brunswick.

Sage is primarily a divinity library and contains materials that support a typical program of training for the Protestant ministry. Such materials include Bibles and commentaries, liturgies, theology old and new, ethics and philosophy, classical and ecclesiastical history, and, increasingly, psychology and sociology. The Reformed Church requires its ministers to know Hebrew and Greek, and therefore Sage has a good selection of classical materials and Judaica. As a divinity library Sage is relatively rich; its collection numbers I 35,000 volumes and 350 current periodicals. The libraries of nearby Princeton Seminary and New York's Union Theological Seminary are much larger, but these two are among the outstanding seminary libraries in the country, and belong to schools far larger in enrollment than New Brunswick, whose approximately I 30 students and faculty enjoy a remarkable access to materials.

Sage is more than a working collection in support of a small seminary program. Simply by virtue of having been in the divinity 


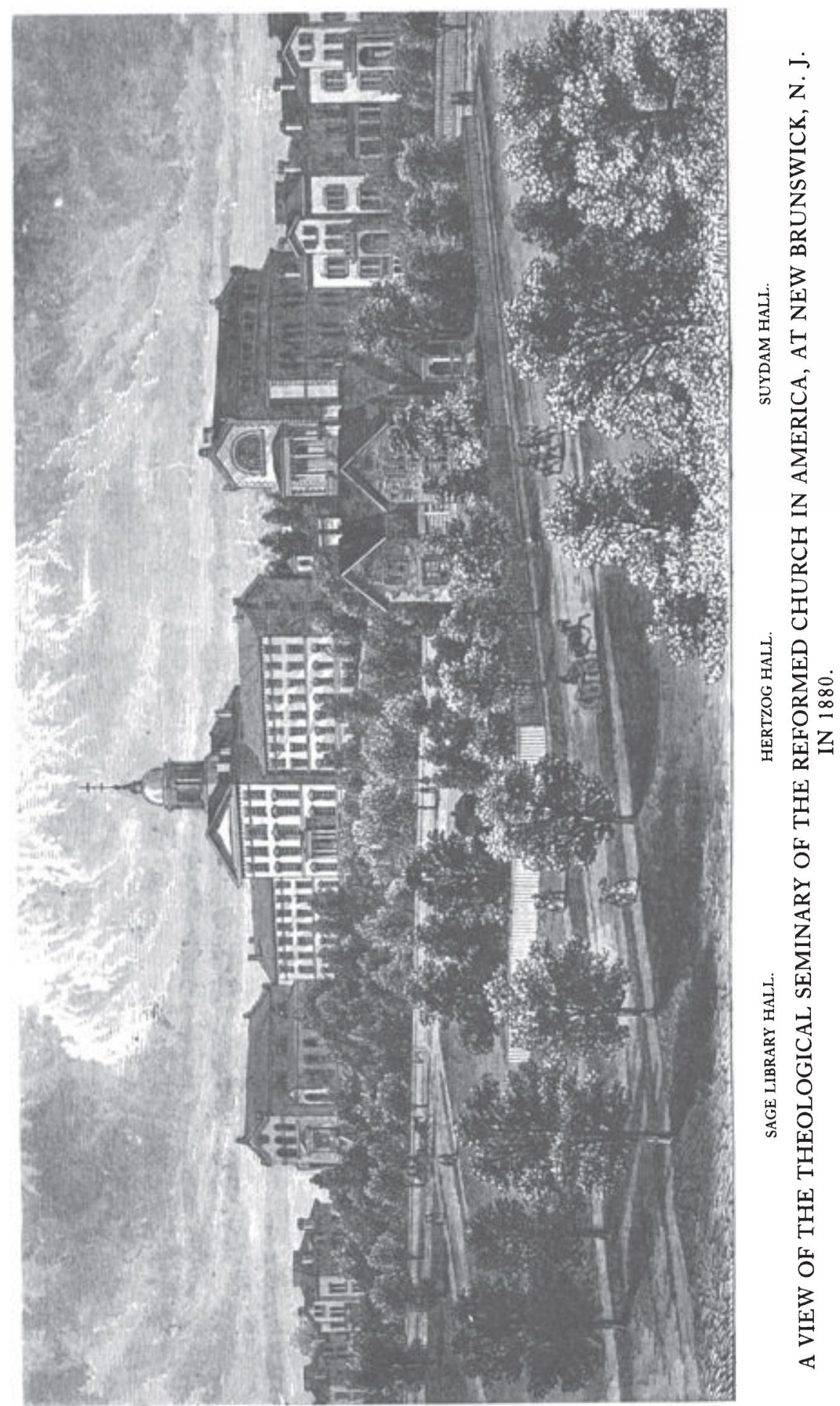


"business" for so long, and of having served a denomination that has valued a university-educated ministry, Sage Library has inevitably developed into a specialized collection of theological, scientific, and literary materials selected-and frequently written-by three centuries of Dutch Reformed ministers. These materials include incunabula, diaries and letters, early imprints of Luther and Calvin, of the rabbis and the Thomists, late Renaissance printing of Plato and Cicero, and first editions by Newtonians and Cartesians. The books appear in all the languages that the Dutch-among the world's greatest linguists-were taught to read. And there appear uncounted numbers of Dutch theological tomes. No nation in the world has produced more native theology than the Netherlands, and no North American library surpasses Sage in this area.

Sage Library is a potentially valuable special collection of scholarly materials. Unfortunately, as a special collection it is awkward, poorly catalogued, and underdeveloped. Few scholars have really used it, and no one really knows exactly what it has, nor how valuable it is. The roots and trunk of a good collection-primary materials - are undoubtedly strong. But the limbs of secondary materials are only tolerably developed, while branches of bibliography and the leaves of modern research and scholarly exploitation are few and scattered. The twentieth century has been unkind to theology, and New Brunswick Seminary as well. There were years when the seminary struggled just to keep its doors open, and Sage Library was neglected. Some church leaders considered Sage more of a liability than a treasure, and only twenty years ago plans were drawn to demolish the lovely building. For decades now Sage has fallen behind other libraries even in the purchase of newer Dutch theological items.

But the approach of the seminary's bicentennial has precipitated new interest in Sage Library as the anchor of the academic program and the pride of the campus. One sign of this is the recent milliondollar-plus fund drive which paid for the restoration of the centuryold-building. The preservation of the rare books inside the building and the development of the collections are just beginning to be addressed.

A first step in this direction has been the exhibition, "The Dutch in Two Worlds: Treasures from the Sage Collection," which has introduced many people to Sage for the first time. The title page 
of the exhibition catalogue reads as follows: "An exhibition of Rare Books, Manuscripts, and Engravings from the Gardner Sage Library of New Brunswick Theological Seminary, celebrating the Seminary's Bicentennial ( 1 784-1983) and the Bicentennial of Peaceful Diplomatic Relations between the Netherlands and the United States (1782-1982). Supported by the New Jersey Committee for the Humanities." The exhibition marks the first time that the seminary has taken full notice of its library-perhaps the critical first step towards the collection's redevelopment. The exhibit has also been winning distant friends for Sage; it has travelled to Holland, Michigan, to Orange City, Iowa, to Berkeley, California, and to the Albany, New York, Institute of History and Art.

\section{The History of the Collection}

Some of the more valuable materials included in the exhibition have to do with the development of the library itself, with the founding of New Brunswick Seminary, and with the establishment of Rutgers University which surrounds it. The Raritan River valley has been called "the garden of the Dutch church." After the I 720 s that garden was the field of a bitter battle among the Dutch over whether Dutch Reformed ministers should be required to have a European education or could be trained in America. The struggle resulted in a schism in the Dutch church in 1755 . One of the two parties succeeded in obtaining a charter for an American school for the primary training of Dutch clergy in I 766, and founded Queen's College, later to become Rutgers University.

In I 77 I the two parties were reunited, and at the close of the American Revolution they organized the Dutch Reformed denomination, modelled upon, in fellowship with, but independent of the mother church in the Netherlands. In I 784 their Synod appointed Dominie John Henry Livingston to be the first Professor of Theology. He taught the first seminarians from his parsonage in Manhattan and also for a time in Flatbush, in Brooklyn. During these years Queen's College led a tenuous existence on the Raritan, opening and closing, and falling into debt.

In 1807 the trustees of Queen's entered into a covenant with the Synod of the Reformed Church. The trustees agreed to appoint Dominie Livingston to the college faculty and presidency in exchange for his bringing the seminary to New Brunswick; further- 
more the Synod would rescue the ailing college by providing money "to purchase a theological library and for erecting a theological hall." The theological hall has become Rutgers University's "Old Queens" and the coat of arms of the Reformed Church can still be seen next to the front doors. The theological library was the beginning of what has become Sage Library. In 18 ro Livingston and the seminary finally arrived in New Brunswick, the schools were joined, and construction of "Old Queens" was begun. In I 8 I 5 the trustees of the college endowed the library with $\$ \mathrm{I}, 800$. In I 8 I 6 the college faltered again, and to save the college from bankruptcy the seminary took over full responsibility for the building, becoming absolute owner of it in 1825 .

In time the college began to revive under the care of the Reformed Church's Synod, which also in I 825 added to its endowment, and renamed the school after a prominent member of the Collegiate Dutch Church in New York, Colonel Henry Rutgers. Soon enrollment was high enough for the college and seminary to find themselves competing for space in their common facility. In I 857 the seminary moved a long block northwest to the next hill (its present site) and there erected a great ark of a building, the "Peter Hertzog Theological Hall," which was demolished over twenty years ago.

Two years later the college library which the two schools had been sharing was divided, "the seminary taking the books that seemed most in its field" (a field much broader in their day than in ours). The result of this division was the seminary's first library per se, which by virtue of its new location was called the "Peter Hertzog Theological Hall Library." The books that were left behind at "Old Queens" formed the first Rutgers College library per se, which ultimately evolved into the Alexander Library. Finally in I 864 the Reformed Church sold "Old Queens" back to the college, which had been a guest in its own home for forty years, and the organic separation of the two schools was complete, libraries included.

"David D. Demarest, "Historical Discourse," in Centennial of the Theological Seminary of the Reformed Church in America in New Brunswick, I784-1884 (New York, I885), p. 90, and E. T. Corwin, Manual of the Reformed Church in America, fourth edition (New York, 1902), p. I 52.

"W.H.S. Demarest, "Historical Address," in The One Hundred Fiftieth Anniversary of the Founding of New Brunswick Theological Seminary (New Brunswick, NJ, 1934), p. 63. 
The "Peter Hertzog Theological Hall Library" was itself not very large or valuable, consisting of textbooks supplied by the Synod, lectures and manuscripts of the professors, and haphazard donations from ministers' libraries (although these were not without their treasures). The first specific gift of I 40 volumes to the combined seminary-college library in I 82 I came from a Mrs. Margaret Chinn of Albany, New York, together with a cabinet to contain them. Ten years later the personal library of Professor John DeWitt, was purchased from his widow with money raised by private subscription; this purchase effectively augmented the school's library by one third. In I 832 a catalog was made listing over 2,000 volumes for both college and seminary.

In I 863, after the libraries had been divided, the seminary was given the private collection of Dr. George Washington Bethune, 3,000 choice volumes, including a number of incunabula. Dr. Bethune had been a leading figure in the Reformed Church; a famous preacher, occasional teacher at the seminary, a poet, traveller, writer, fisherman (he published an edition of Walton's The Compleat Angler), and sometime minister of the American church in Florence, Italy. Many of Sage's most valuable books bear Bethune's book stamp, and a large bust of him is in Sage's book hall today. Other gifts and purchases added their value to the Hertzog Hall Library, which attained a size of 8,000 volumes in 1873 .

The second half of the nineteenth century was the seminary's golden age, even though the younger Presbyterian seminary down the road at Princeton had quickly surpassed it in size and importance. The Reformed Church as a whole was prospering and expanding both in America and overseas. The denomination was disproportionately influential in the great missionary movement of the time, and the seminary was the nursery for its missionaries. The denomination had also developed a corps of church leaders that felt great loyalty to the seminary, and these devoted energy and money to the school's success. Indeed, the school came to be the pride of the denomination, even though the same leaders had founded a second theological faculty in Holland, Michigan in I 866 to serve the new influx of nineteenth-century Dutch immigrants to the Midwest.

The Synod erected two more buildings on the campus, in 1873 a classroom building flanking Hertzog Hall to the east, and in 
I 875 a matching library building to the west. The classroom building was demolished several years ago, but the library building still stands as the home of the collection. It was designed to shelve 40,000 books, and cost $\$ 65$,000. The architect was a Paris-trained German named Detliff Lienau, the popularizer of the mansardroof in this country. The supervising engineer of the building was the donor himself, Gardner A. Sage of New York City, who, according to seminary mythology, was Frederick Law Olmstead's engineer for the construction of Central Park. Sage commuted daily to New Brunswick to supervise the construction, donated a further $\$ 35$, 000 for supplies and maintenance, and added another $\$ 20,000$ for the purchase of books to fill the empty shelves. The Hertzog Hall collection was moved into the new building, and finally became the Gardner A. Sage Theological Library,

The building far surpassed the collection. But the completion of the luxurious facility spurred the church's interest in the collection itself. The Synod appointed alumnus James A.H. Cornell, a descendent of the Frelinghuysens, to see that the seminary acquire a first-rate collection. He gathered the sum of $\$ 50$, 000 from various donors, not for endowment but for the purchase of books outright. A committee of the best minds among the denomination's clergy ${ }^{3}$ was appointed to work together with the seminary faculty. For ten years the committee met monthly, raised more money, spent a total of $\$ 60,000$ in the purchase of sources and reference materials from both American and European publishers, and invested in "volumes and series of volumes of rare worth here and abroad." 4

${ }^{3}$ Members of the committee were the Revs. James A. H. Cornell, Financial Agent of the General Synod, Talbot W. Chambers, Minister of the Collegiate Dutch Church in New York City, E. Tanjore Corwin, Minister of the Hillsborough Reformed Church in Millstone, NJ, Chester Hartranft, Minister of the Second Reformed Church in New Brunswick, NJ, and Professor Jacob Cooper of the Rutgers College Faculty. Corwin became the great historian of the Dutch church, and later edited the six volume Ecclesiastical Records of the State of New York (I90I-I9I6). Chambers served the leading church in the denomination, and was known not only as a pulpiteer but also a scholar, author, and ecumenical leader. Hartranft went on to become professor and president of the Hartford Theological Seminary, in its time one of the leading theological schools in the country. But the leader of the group seems to have been Cornell, who is not well known even though he raised over half a million dollars for the seminary in ten years. Except for his nine years as an agent of the General Synod, he served as a simple country pastor. Yet of him Dr. Norman Kansfield, Theological Librarian at Colgate-Rochester Divinity School in Rochester, NY, said to the author, "Cornell was the real genius of that committee, and the most important contributor of all to Sage Library from beginning to end."

4 W.H.S. Demarest, op. cit., p. 65. 
By I 879 the committee had purchased 27,000 volumes to bring the total to 35,000 (whereas the complete collection of Rutgers College three years later numbered only about io,000 volumes). ${ }^{5}$ A later librarian would claim that there was no finer seminary library in the country. ${ }^{6}$ The collection was further enhanced by manuscripts and scrolls dutifully sent back to New Brunswick by alumni who were missionaries; in those days the poorer nations had not yet learned to protect their native treasures from the covetousness of Christendom.

In 1876 the Reverend Peter J. Quick was appointed as the first full-time librarian, and two years later the remarkable John C. Van Dyke became his assistant. When the former suddenly died, Van Dyke assumed the position of librarian and served with various assistants for fifty-four years, through 1932. His is perhaps the most important single name connected with Sage Library. Neither a clergyman nor theologian, Van Dyke was never a full member of the seminary faculty. Although he was certainly congenial to Biblical studies and theology, and in I 888 published his Notes on Sage Library (which would see later editions), Art History was Van Dyke's first love, and eventually he held a simultaneous appointment as Professor of the History of Art at Rutgers College. He wrote thirty-five books on the subject as well as several articles in standard encyclopedias, ${ }^{7}$ and developed for Sage a small gem of an art collection (the Vedder Collection, which has since been sold).

Partly as a result of Van Dyke's personal interests, the library's collection failed to be developed in the area of its uniqueness. Just at a time when Dutch theology and philosophy had entered a new era of controversy and vigor, Dutch publications of interest to both continents and closely akin to the volumes already in Sage ceased to be systematically acquired. There are other reasons for this failure besides the person of the librarian. First, unlike Princeton and Union Seminaries, New Brunswick had never initiated the doctorallevel programs in theology that would have demanded such publications. And second, the inevitable absorption of the denomination

s Ibid., A History of Rutgers College: 1766-1924 (New Brunswick, NJ, 1924), p. 460.

"John C. Van Dyke, "The Sage Library," in The New Brunswick Seminary Bulletin 6 (April I931): I5.

7E.G.: "Painting: United States" in Encyclopaedia Britannica, eleventh edition (New York, I9 IO). 
into the majority English culture of America made it easier for students to read the theology of their Scots Presbyterian friends than of their Dutch Reformed cousins.

Van Dyke was not the one to counter these movements. Nonetheless, the strength of his commitment to the classics and to the liberal education that historically are the underpinnings of $\mathrm{Re}$ formed theology, coupled with his own activity in the world of letters and his standards of taste combined to make his legacy to Sage Library a rich one. Curiously enough, however, though the seminary sang Van Dyke's praises in later years, it did not feel the need to replace him with a full-time successor upon his retirement. The library that had been at one time the object of the church's lavish affections had declined in status over fifty years to being simply the seminary's big bookshelf. Succeeding Van Dyke was the Rev. Edward Worcester, who simply added the librarianship to his other duties as the seminary's Professor of Theology.

When Worcester died in 1937 he was succeeded by his assistant, Ms. Dorothy Wilson. She was full-time, and ever since her tenure Sage has not suffered from understaffing, at least in the area of technical services. She and her eventual successors, the Rev. Peter Nicholas VandenBerge (1957-1967), and the Rev. David LeRoy Engelhardt ( I 967-present) have reflected the seminary's commitment to maintain the library as a support for Protestant divinity training, but little more. Perhaps the recent renovation of the building and the improved storage for the rare books is the signal that a change has come.

\section{The Library Building}

The edifice of I 875 was built in the style of a "book hall." This design for libraries had been used in 1695 for Trinity College in Dublin (home of "The Book of Kells") and also for Trinity College at Cambridge. According to seminary president Dr. Howard Hageman, "the book hall design prevailed in approximately 80 percent of the academic libraries constructed in the United States between I 840 and I 880, including Harvard and Yale." 8 The "book hall" is one type of the large "reading room" that was the architectural heart of nineteenth-century libraries. Such reading rooms

\footnotetext{
${ }^{8}$ As quoted in The Home News, New Brunswick, NJ (April 23, 1981), p. I I.
} 

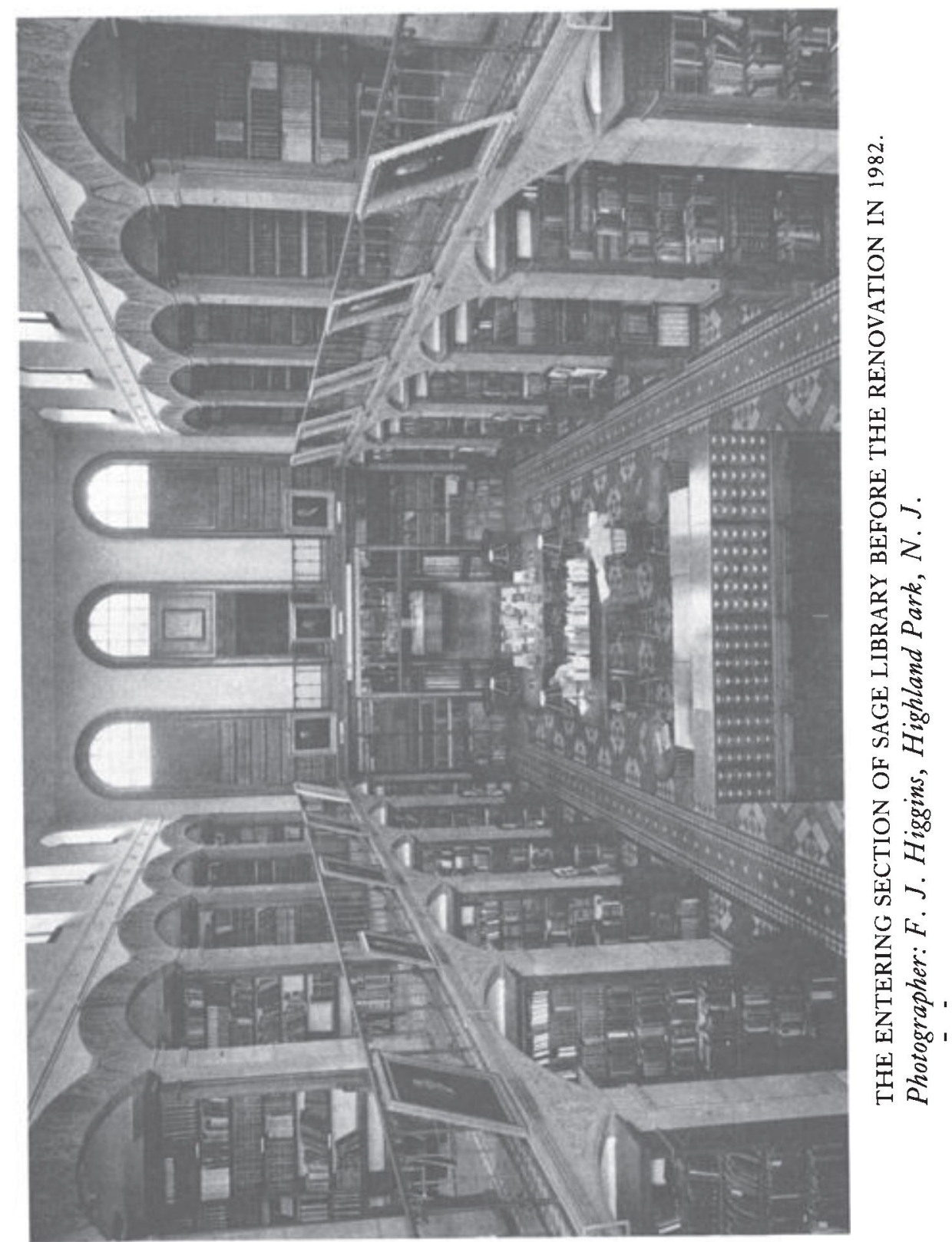
were inspired by Henri Labrouste's Parisian masterpiece, the library of Sainte Geneviéve (i 850 ), and were subsequently repeated in the great public libraries of New York and Boston. Grand spaces have since gone out of fashion in public buildings, from libraries to railroad terminals, and the next generation of library buildings were built differently, much larger in total bulk, but packed with numerous much smaller rooms and spaces. (Yet the lofty atrium of the new library at New York University and the "sky-lobbies" of modern hotels suggest that grand spaces may return in new forms.)

Most of the academic "book halls" were demolished in favor of the more modern design, again including Harvard and Yale. Sage Library is one of only four book halls still in use in the United States today, and "probably comes as close as any of the four to retaining all its original characteristics, appointments, and furnishings. Typically, the book hall was a high-ceilinged, rectangular room, with book stacks ranging inward at the pilasters from the longer walls, forming alcoves, with a window in each, and allowing a large central area for reading tables. In most cases, the alcoves were repeated in one or more galleries above, with the room further lighted through celestory windows at the top."

Sage epitomizes the type, with its two levels of seven alcoves along each side of the hall, and celestory windows above. The high ceiling is Italianate plaster, and the floor is an elaborate mosaic of large red, beige, brown, and black Minton tile. A gallery grants access to the upper alcoves, and with its wrought iron balustrade also gives definition and scale to the hall. In I 922 stained glass was installed in the windows of the lower alcoves, each window memorializing a family that contributed to the endowment. The basement repeats the floor plan of the hall above it, and is used for the storage of periodicals.

Due to the growth of the collection, which had reached 56,000 volumes and I0,000 pamphlets by I 929 , the building was expanded in that year with what Van Dyke called "transepts, crossing, and an apse" added to the north end of the existing hall, the "Wessels Wing." The addition nearly doubled the capacity of the building, and provided smaller rooms for the Vedder Art Collection, the

9 Ibid. 
Bible collection, Classics, Dutch documents, and technical services. But circulation and cataloging were kept at their former place in the hall, and the sounds of telephones and typewriters echoed constantly in the alcoves.

The recent renovation of the building has completely rebuilt the interior of the Wessels Wing while leaving the book hall intact. All technical services have been moved to the newer wing, allowing the hall to enjoy the quiet dignity of a reading room. It is furnished exclusively with large wooden tables and table-lamps, Windsor chairs, and a handsome freestanding walnut reference bookcase which matches the style of the surrounding alcoves.

\section{The Collection}

Gardner Sage Library is an important source of materials that relate to the general history and culture of the Dutch in America. Along with the New-York Historical Society, Sage possesses the greatest recorded number of surviving copies of colonial DutchAmerican imprints. ${ }^{\circ}$ Besides these are manuscripts and letters, the years of correspondence with the Classis of Amsterdam of the mother church, and the Archives of the Reformed Church in America and its congregations, including consistory minutes and baptismal, marital, and death records.

Sage also holds many Netherlandic imprints of the seventeenth and eighteenth centuries, the "Golden Age" of Dutch culture and printing. Among these are first editions of Hugo Grotius, complete sets of Bor's Historie der Nederlandsche Oorlogen ( I 679, History of the Dutch Wars), Wagenaar's Vaderlandsche Historie ( I 754, History of the Fatherland) and Amsterdam Beschreven ( 760 , Amsterdam Described), the Groot Placaet-boeck, I658-I 797 (Collected Edict and Laws), twenty-nine volumes of Vander Aa's Zee en Land Reysen na Oost en West Indien (Voyages and Expeditions to the Indies), Van Loon's Beschrijuinge der Nederlandsche Historiepenningen (1723, Dutch Commemorative Coins and Medallions), Van Mieris' Histori der Nederlandsche Vorsten ( 1732, Dutch Nobility), an edition of Melis Stoke's Rijm-Kronijk (1699, Rhymed Chron-

${ }^{\circ}$ Hendrik Edelman, Dutch-American Bibliography 1693-1749 lists eleven imprints that belong to the New-York Historical Society and ten that belong to Sage. One of Sage's ten, a duplicate of Edelman \# 75, has since been presented to the Royal Library in the Hague to commemorate the visit of Queen Beatrix to Sage in 1982. But two more imprints have been discovered at Sage, as listed in the appendix above, which brings the total to eleven. 
icle), and the Verhandelingen (Acts and Treatises) of the Holland Academy of Sciences at Haarlem, 1757-1787. When these were published, Dutch cities and universities had few rivals in Europe.

Dutch ministers were expected to be university-trained, even in America, and they would naturally have enjoyed such books as the above, which came to Sage by way of parsonage libraries. But the primary interest of Dutch ministers was, of course, theological, and consequently there is no finer collection outside of the Netherlands, of early Dutch and Latin theological and religious books by Dutch authors than Sage Library. This includes the few surviving sermons, polemical tracts, and catechisms published by the Dutch clergy of New York and New Jersey such as the Frelinghuysens, Bernardus Freeman, Johannes Leydt, and Tobias Boel. It includes hundreds of manuscript sermons by Dominies Livingston, Laidlie, Lynn and others preached in both English and Dutch. But it also includes first editions by the scholastic Calvinistic theologians at the European universities, such as Perkins, Ames, Turretin, Voetius, Coccejus, Wollebius, Wittsius, the Synodical Acts and Canons, and the liturgies and psalm-books of the national Reformed church. Sage also holds extremely rare copies of imprints dating from the era of the Reformation in the Netherlands, including first editions by Erasmus ( I 5 I 9, I 526), Wessel Gansvoort (I 52 I), David Joris (I 55I), and by others less well known, and also many more second and third editions from the same era.

Supporting this unique collection of Dutch theological materials in a strong selection of publications from the broader Renaissance and Reformation movements, representing such great printing houses as the Aldine, Froben, Stephanus, and Crespin. To this group belong the Erasmus New Testament ( 5 I 9), the first quarto New Testament (1521) by Grabelius, the first collected Luther (I 546I 579), three first editions of Calvin ( I 556, I 557, I 560), two classical authors with manuscript notes and verses in the hand of Philip Melanchthon, the Beza New Testament ( I 559), and the first book printed in Syriac, a Bible ( I 559 ). Sage's collection of classical, patristic, medieval, and renaissance authors includes the following incunabula; Albertus Magnus ( 1480 ), Ambrosius ( I 492), Campani (1495), Cassiodorus (1472), Herbert de Silgenstadt ( I 483), Occam (1495), Peter Lombard (I 488), Thesaurus semonum Nuremburgaes (I 487), Alexander de Hales (four volumes, I 48 I-I 482), 
and Suetonius ( 1496 ). Alongside these is a manuscript Coptic grammar from I 440 and four different Arabic commentaries from the thirteenth century.

In 1964 three manuscripts were found inside the bindings of a three volume edition of the works of Saint Ambrose (Basel: Johann Amerbach, I 5 I6, n.d. I 5 I6?, I 492). "Volume I yielded a passage from Giraldus Cremonensis' still unpublished Latin translation of Aristotle's Meteora (Book II), Volume II a segment from an Old French translation of the Book of Judges ...., Volume III two hundred lines from a hitherto unknown old French poem dealing with the miracles performed by the Apostle Andrew while he was converting Greece to Christianity." I The latter two fragments have both been discussed in articles published by Gerald Bertin and Alfred Foulet, who have dated both manuscripts, with some uncertainty, to the decade around A.D. I 200, and have called the second fragment "the sole extant segment of a manuscript which is probably the most archaic translation into French of the Book of Judges." "12

None of Sage's incunabula has been adequately described using modern methods of scholarly bibliography. The same is true for the hundreds of sixteenth-century imprints and the thousands from the seventeenth century. In fact, the preparations for "The Dutch in Two Worlds" exhibition turned up the existence of several extremely rare volumes previously unlisted anywhere except in Sage's card catalog. This includes one incunabulum and two colonial DutchAmerican imprints. These books have been listed in detail in an appendix to this article.

That the existence of such volumes - even an incunabulum-has gone unnoticed in the middle of a university town is a measure of the tragic underutilization of Sage Library by scholars. Of course there have always been seminary professors who have exploited the collection in the course of their research-most recently these have included professors John Beardslee and Howard Hagemen. But there have been only a few other projects that have explored Sage. There is Rutgers University Librarian Hendrik Edelman's Dutch-

"Gerald A. Bertin and Alfred Foulet, "The Acts of Andrew in Old French Verse: The Gardner A. Sage Library Fragment," PMLA, 8 I (Oct., I 966), p. 45 I.

12 Gerald A. Bertin and Alfred Foulet, "The Book of Judges in Old French Prose: The Gardner A. Sage Library Fragment," Romania 90:I (1 969), p. I 21. 
American Bibliography I693-I794 (Nieuwkoop, I 974). Dr. James Tanis, who is Director of Libraries at Bryn Mawr College, also used Sage in preparation for his 1967 dissertation for the University of Utrecht called Dutch Calvinistic Pietism in the Middle Colonies: A Study in the Life and Theology of Theodorus Jacobus Frelinghuysen (The Hague, 1967). Further, Sage was used by Jack Martin Maxwell for his Worship and Reformed Theology: The Liturgical Lessons of Mercersburg (Pittsburgh, I976). In I 979 the port of Yokohama sent Professor Michio Takaya to Sage in order to microfilm more than 20,000 pages of documents and records belonging to the Board of Foreign Missions of the Reformed Church deposited in the Archives. The Rev. Jack Klunder is currently preparing a dissertation for Westminster Theological Seminary on the topic of Dutch Reformed preaching in eighteenth-century America, and his work so far has included an annotated bibliography which abstracts every known sermon of the period in Sage, manuscript or printed, in Dutch or in English, completely cross-referenced with a subject index. It must be added that there have been the several hundred masters' theses written by certain New Brunswick seminarians, but none of these has been published.

The field of Dutch-American studies is a small one within the wide landscape of scholarship, and the theological corner of that field is hardly the most attractive to contemporary students, but that is the corner where Sage has been planted. The resources that Sage Library can boast of are not likely to be used by outside scholars unless the seminary makes them more accessible through bibliographic work and modern technical services. But the increased costs of such accessibility must be justified against the constraints of a limited seminary budget and also against the recent steps taken by the school towards the specialization of the program of instruction in urban and minority education. At first glance the unique holdings of the collection seem hardly relevant to this kind of instruction.

The experience of recent decades has shown that innovative programs in divinity education, like paper money, quickly lose their value unless they are backed by solid gold; in this case not ingots but books. The future direction and specialization of the seminary does not at all rule out the development of the special collections at Sage. But for the library to develop according to its potential 
not only requires a more worthy budget and aggressive acquisition policy, but also some creative theology and bibliography on the part of the faculty and staff.

Full and imaginative development of Gardner Sage Library's potential must be undertaken primarily in order to better serve the seminarians and the new urban and minority education programs. One imagines a bibliography that would list not only the recent classic, A Theology of Liberation ( 1 973) by Gustavo Gutierrez, but also Adriaen van Haemstede's Historie der Marteleren ( I658, History of the Martyrs), not only Jose Miguez-Bonino's Christianity and Marxism (1976) but also the radical Anabaptist David Joris' Wonderboeck ( $155 \mathrm{I}$ ). One imagines an exhibition setting Harvey Cox's The Secular City (1965), a landmark in urban theology, side by side with the three folio volumes of Caspar Commelin's $B e$ schryvinge van Amsterdam ( I 726) describing in minute detail every orphanage, deaconry, church, and tobacconist in that great city. Secondly, the Library's development must be undertaken to serve outside scholars through a painstaking bibliographic evaluation of the collection and comparison with other libraries. This latter task especially is an enormous one for a small institution like the seminary, but it looks far more possible in the year of the school's bicentennial than it did even two years ago.

\section{Appendix}

The research done in preparation for "The Dutch in Two Worlds" exhibition; of which the author of this article was the director, has resulted in the discovery of previously unknown copies of the following four rare books.

I. Breviarum Carmelitanum, published in Brussels on May I6, I 480. This incunabulum is listed as item \# 5192 in the Gesamtkatalog der Wiegendrucke, and described in detail in volume $V$, columns I I 5-I I 7. The Gesamtkatalog lists a dozen copies of this first printed prayer book of the Carmelite Order, and none are in the Western Hemisphere. Brother Valentinus of Cologne, its editor, was a member of the Brethren of the Common Life, an order of lay brothers common in the cities of the Netherlands and influential in the reform of the Roman Catholic Church.

2. Liturgia Sacra (Valerandus Pollanus et al.) published in Frankfort-on-Main in I 554. This is the liturgy of the Calvinist refugee 
congregation which was organized in London under Pollanus. It was published there first in I $55 \mathrm{I}$ and again in 1552 . A year later the accession of Queen Mary to the throne forced the refugees into further exile in the German city of Frankfort. Two more editions were published, in I 554 and I 555. This liturgy is of great importance because it was used in the preparations of the Heidelberg liturgy of I 563 and the later national liturgies of the Reformed churches of the Netherlands and Hungary.

A modern critical edition of the Liturgia Sacra was published by Dr. A. C. Honders (Liturgia Sacra I 55 I-I 555 , Leiden, I 970) which includes a bibliography. Honders lists eleven remaining copies of the work, and knows of none in the Western Hemisphere. The Sage copy is the fifth remaining copy, then, of the third edition, and the only one outside Europe.

3. Bernardus Freeman, Verdeediging van Bernardus Freeman, "Nieuw-York," I 726. This is item number 9 in Edelman's DutchAmerican Bibliography I693-1794, which records only two remaining copies, one at the Library Company of Philadelphia and the other at the Long Island Historical Society. Like the latter of the two, this third copy lacks a title page.

4. (Nederlands Hervormde Kerk, Kerkenraad van Amsterdam) Nadere Trouwhartige Waarschouwinge, Nieuw-Jork, 1763. This is item 79 in Edelman's bibliography, and two previously recorded copies are also in the Library Company of Philadelphia and the Long Island Historical Society. 